\title{
BOUNDARY VALUE PROBLEMS FOR FRACTIONAL
}

\section{DIFFERENTIAL INCLUSIONS IN BANACH SPACES}

\author{
MoufFak Benchohra, Johnny Henderson and DJamila Seba
}

Abstract. This paper is concerned with the existence of solutions of nonlinear fractional differential inclusions with boundary conditions in a Banach space. The main result is obtained by using the set-valued analog of Mönch fixed point theorem combined with the Kuratowski measure of noncompactness.

Mathematics subject classification (2010): 26A33, 34A60, 34B15.

Keywords and phrases: differential inclusions, Caputo fractional derivative, boundary value problem, Banach space, existence, fixed point, measure of noncompactness.

\section{REFERENCES}

[1] R. P. Agarwal, M. Benchohra And S. Hamani, Boundary value problems for differential inclusions with fractional order, Adv. Stud. Contemporary Math. 16, 2 (2008), 181-196.

[2] R. P. AgARwAl, M. BENChOHRA AND D. SEBA, On the application of measure of noncompactness to the existence of solutions for fractional differential equations, Results Math. 55, 3-4 (2009), 221230.

[3] B. Ahmad And S. K. NTOUYAS, Some existence redults for boundary value problems of fractional differential inclusions with non-separated boundary conditions, Electron. J. Qual. Theory Differ. Equ. 71 (2010), 1-17.

[4] R. R. Akhmerov, M. I. Kamenskit, A. S. Patapov, A. E. Rodkina and B. N. Sadovskit, Measures of noncompactness and condensing operators, Translated from the 1986 Russian original by A. Iacob. Operator Theory: Advances and Applications, 55. Birkhauser Verlag, Basel, 1992.

[5] J. BAnAs̀ AND K. GoEBEL, Measures of Noncompactness in Banach Spaces, In Lecture Notes in Pure and Applied Mathematics, Volume 60, Marcel Dekker, New York, 1980.

[6] M. BEnCHOHRA, A. CABADA, AND D. SEBA, An existence result for nonlinear fractional differential equations on Banach spaces, Bound. Value Probl., Volume 2009 (2009), Article ID 628916, 11 pages

[7] M. Benchohra And S. Hamani, Nonlinear boundary value problems for differential inclusions with Caputo fractional derivative, Topol. Meth. Nonlinear Anal. 32, 1 (2008), 115-130.

[8] M. Benchohra, S. Hamani, J. J. Nieto And B. A. Slimani, Existence of solutions to differential inclusions with fractional order and impulses, Electron. J. Qual. Theory Differ. Equ. 80 (2010), 1-18.

[9] M. Benchohra, N. Hamidi AND JuAn J. Nieto, Topological transversality method and fractional order differential equations, Comm. Appl. Nonlinear Anal. 17 (2010), 25-34.

[10] M. BEnChohra, J. Henderson AND S. K. NTOUYAS, Impulsive Differential Equations and Inclusions, Hindawi Publishing Corporation 2, New York, 2006.

[11] M. Benchohra, J. Henderson, S. K. Ntouyas And A. OuAhab, Existence results for fractional functional differential inclusions with infinite delay and application to control theory, Frac. Calc. Appl. Anal. 11, 1 (2008), 35-56.

[12] M. Benchohra, J. Henderson And D. Seba, Measure of noncompactness and fractional differential equations in Banach spaces, Commun. Appl. Anal. 12, 4 (2008), 419-428.

[13] M. Benchohra, G. M. N'GuÉrÉKAtA And D. SEBA, Measure of noncompactness and nondensely defined semilinear functional differential equations with fractional order, CUBO A Math. J. 12, 3 (2010), 33-46. 
[14] M. Benchohra, J. J. Nieto And D. Seba, Measure of noncompactness and hyperbolic partial fractional differential equations in Banach spaces, Panamer. Math. J. 20, 3 (2010), 27-37.

[15] M. BEnCHOHRA AND D. SEBA, Impulsive fractional differential equations in Banach spaces, Electron. J. Qual. The. Differ. Equa. Spec. Ed. I 8 (2009), 1-14.

[16] M. BENChohra And D. SEBA, Measure of noncompactness and partial differential equations involving Riemann-Liouville fractional derivative, Dynam. Systems Appl. 19 (2010), 527-536.

[17] Y. K. Chang AND J. J. NiETo, Some new existence results for fractional differential inclusions with boundary conditions, Math. Comput. Modelling 49 (2009), 605-609.

[18] M. A. DARWISH AND S. K. NTOUYAS, On initial and boundary value problems for fractional order mixed type functional differential inclusions, Comput. Math. Appl. 59, 3 (2010), 1253-1265.

[19] K. Deimling, Multivalued Differential Equations, Walter De Gruyter, Berlin-New York, 1992.

[20] A. M. A. El-SAYed AND A. G. IBrahim, Set-valued integral equations of fractional-orders, Appl. Math. Comput. 118 (2001), 113-121.

[21] M. FRIGON, Systems of first order differential inclusions with maximal monotone terms, Nonlinear Anal. TMA 66 (2007), 2064-2077.

[22] V. Gafiychuk, B. Datsun and V. Meleshro, Mathematical modeling of time fractional reaction diffusion systems, J. Comp. Appl. Math. 220 (2008), 215-225.

[23] S. HAMANI, M. BENCHOHRA AND J. R. GRAEF, Existence results for boundary-value problems with nonlinear fractional differential inclusions and integral conditions, Electron. J. Differential Equations bf 20 (2010), 16 pp.

[24] J. H. HE, Approximate analytical solution for seepage flow with fractional derivatives in porous media, Comp. Meth. Appl. Mech. Eng. 167 (1998), 57-68.

[25] H. P. HEINZ, On the behaviour of measures of noncompactness with respect to differentiation and integration of vector-valued functions, Nonlinear Anal. 7 (1983), 1351-1371.

[26] R. Hilfer, Applications of Fractional Calculus in Physics, Singapore, World Scientific, 2000.

[27] S. Hu and N. Papageorgiou, Handbook of Multivalued Analysis, Kluwer, Dordrecht, Boston, 1997.

[28] G. JUMARIE, An approach via fractional analysis to non-linearity induced by coarse-graining in space, Nonlinear Anal.: Real World Appl. 11 (2010), 535-46.

[29] A. A. Kilbas, H. M. SRivastava and J. J. Trujillo, Theory and Applications of Fractional Differential Equations, North Holland Mathematics Studies, 204, Elsevier Science B.V., Amsterdam, 2006.

[30] A. Lasota And Z. Opial, An application of the Kakutani-Ky Fan theorem in the theory of ordinary differential equations, Bull. Acad. Pol. Sci., Ser. Sci. Math. Astronom. Phys. 13 (1965), 781-786.

[31] Y. F. Luchko, M. Rivero, J. J. Trujillo And M. P. Velasco, Fractional models, non-locality and complex systems, Comp. Math. Appl. 59 (2010), 1048-1056.

[32] D. O'REgAn AND R. PRECUP, Fixed point theorems for set-valued maps and existence principles for integral inclusions, J. Math. Anal. Appl. 245 (2000), 594-612.

[33] I. Podlubny, Fractional Differential Equations, Mathematics in Science and Engineering, vol. 198, Academic Press, San Diego, 1999.

[34] J. Sabatier, O. P. Agrawal and J. A. T. Machado (Eds.), Advances in Fractional Calculus: Theoretical Developments and Applications in Physics and Engineering, Springer, Dordrecht, 2007.

[35] G. V. SMIRnov, Introduction to the Theory of Differential Inclusions, American Mathematical Society, Providence, RI, 2002. 